\title{
Application of BASINS/HSPF in the Koycegiz-Dalyan watershed in Turkey: a developing country case study in watershed modeling
}

\author{
M. A. Baloch ${ }^{1}$, D. P. Ames ${ }^{2}$ \& A. Tanik ${ }^{1}$ \\ ${ }^{1}$ Department of Environmental Engineering, \\ Istanbul Technical University, Istanbul, Turkey \\ ${ }^{2}$ Department of Geosciences, Idaho State University, Idaho Falls, USA
}

\begin{abstract}
A dynamic simulation model, HSPF (Hydrological Simulation ProgramFORTRAN), is used for the simulation of hydrology and diffuse pollution in the Namnam sub basin of Koycegiz-Dalyan watershed in Turkey using a minimum amount of data required for model application. The resulting correlation coefficients for the mean daily and monthly flows for the Namnam stream were found to be 0.634 and 0.847 for calibration, and 0.761 and 0.843 for validation, respectively, using the Expert System for the calibration of HSPF (HSPEXP). HSPEXP criteria for calibration of HSPF based on the comparison of statistics between simulated and observed flows varied from fair to very good, except for the summer flow volume and total of the lowest $50 \%$ flows. Sediment, nitrate-N, orthophosphate-P, and BOD loads were determined for different land uses in the Namnam watershed. Agricultural activity was identified as the major source of sediments, and pastures with livestock grazing produced the highest NPS fluxes. The results emphasize the importance of advanced modeling tools even in the absence of high quality, continuous and consistent data.
\end{abstract}

Keywords: developing countries, hydrologic modeling, data stringent conditions, watershed modeling, BASINS/HSPF, HSPEXP, NPS pollution. 


\section{Introduction}

Integrated Watershed Management (IWM) incorporates a systematic approach for identification, analysis, and mitigation of complex environmental problems on watershed scale $[1,2]$. The complexity and magnitude of watershed systems often necessitate the adoption and application of dynamic watershed simulation modeling techniques to achieve the goals of IWM [3, 4]. These are essential and effective tools for investigating the complex nature of the hydrologic processes that affect soil erosion, fate and transport and of contaminants in watersheds, and for the assessment of the impacts of land use changes, agricultural activities, and best management practices on these processes [5].

Despite their ubiquity and often comprehensive structure, many of the watershed models have not yet become standard tools in hydrological and watershed management practices in developing countries [6]. Insufficient monitoring programs for the collection and gathering of watershed data due to lack of financial resources limits opportunities for watershed and water quality researchers to engage in active research for the solution of complex watershed problems. This paper endeavors to apply a detailed watershed model to simulate hydrology and non-point source (NPS) pollution in an ecologically important watershed in a developing country. This study was carried out under data-poor conditions using the absolute minimum amount of data required for the application of the model. The stringent or data-poor conditions imply availability of only the absolute minimum required data as inputs for populating and executing a model. These datasets may not have the appropriate consistency, continuity, temporal and spatial coverage, and resolution available for enhancement and estimation procedures.

NPS pollution is closely associated with hydrological processes in a watershed. However, it has a random nature due to the lack of strictly defined spatial and temporal attributes. Conversely, hydrology defines many processes in a watershed and its characterization can help conservation and sustainable management of watershed resources [7]. For the characterization of hydrology and NPS pollution in a watershed in a developing country under data-poor conditions, a watershed scale distributed and continuous model capable of simulating hydrology, NPS pollution, and biogeochemical processes is considered to be most suitable. Hydrological Simulation Program-FORTRAN (HSPF) is a widely used distributed, continuous watershed model. It is supported by the US EPA and is incorporated as its core watershed model into the Better Assessment Science Integrating Point and Non-point Sources (BASINS) watershed analysis system. The BASINS system [8] integrates data acquisition, data pre-processing/post-processing, watershed characterization, application of models, interpretation of model results, and development of maps and tables using its data processing tools WDMUtil and GenScn, core HSPF model (in the form of WinHSPF) and underlying MapWindow GIS platform for delineation and characterization of watersheds [9]. The selection of HSPF is further justified by the availability of the Expert System for Calibration of HSPF (HSPEXP) and a database of HSPF parameters from past calibration studies known as HSPF- 
Parm developed by the US EPA to assist watershed modelers in calibrating HSPF $[10,11]$. Considering the deficiency in data needed for the estimation of model parameters, the availability of these tools is a major advantage in using BASINS/HSPF for solving watershed scale environmental problems in developing countries [12]. HSPF can simulate the dynamic event or steady-state behavior of both hydrologic and water quality processes in a watershed, with an integrated linkage of surface, soil, and stream $[5,13,14]$. Because of its modular design, HSPF can be used for a range of simple to complex watershed simulations including urban and agricultural land use, surface and subsurface processes, runoff, sediment export, and the fate and transportation of nutrients, pesticides, and other water quality constituents $[11,15]$. HSPF has been used successfully to model the stream hydrology and quantities of sediment, nutrients, and pesticides from agricultural lands [16-18].

The objective of this study is to use BASINS/HSPF for the characterization of hydrology and NPS pollution in the Namnam sub-basin of Koycegiz-Dalyan watershed in Turkey. Despite being a developing country, there have already been efforts towards application of HSPF in Turkey. Albek et al. [19] used HSPF for the hydrological modeling of the Seydi Suyu watershed. Goncu and Albek [20] studied the effects of climate change on the hydrology of watersheds by modeling climate change scenarios on a hypothetical watershed with different land use simulations using HSPF. Yuceil et al. [21] used HSPF for development of a model support system for rural NPS modeling in their case study watershed. This study expands the work by Yuceil et al. [21] and introduces the GIS capabilities of BASINS and the HSPEXP tool to simulate hydrology and NPS pollution in the Namnam sub-basin.

\section{Study area}

The Koycegiz-Dalyan Watershed is located in the southwest of Turkey as shown in Figure 1 and includes the Koycegiz Lake that joins the Dalyan Lagoon which in turn joins the Mediterranean Sea. It is one of the most sensitive and vulnerable coastal regions of the country in terms of endangered and endemic species. The geology of the watershed bears karstic characteristics. The seasonal groundwater variations are 0.05-6.55 $\mathrm{m}$ between May and November. The groundwater discharge of the plains occurs through artificial discharge and groundwater flow directly to the sea [21]. Primary rivers that feed Koycegiz Lake are the Namnam and Yuvarlak streams. The only outlet of the Koycegiz Lake is the Mediterranean Sea through the Dalyan Lagoon Channel System. Namnam is the largest stream, with its basin representing $45 \%$ of the entire Koycegiz-Dalyan watershed and $62 \%$ of the Lake sub-watershed. The Namnam sub-basin system shows a flow pattern that is primarily precipitation mandated. Groundwater contribution is assumed to be less significant, as a majority of its large basin is covered with a very shallow soil with an impervious rock formation underneath. Hence, even without the groundwater flow data, it was possible to calibrate and validate a usable hydrological model for this basin. 


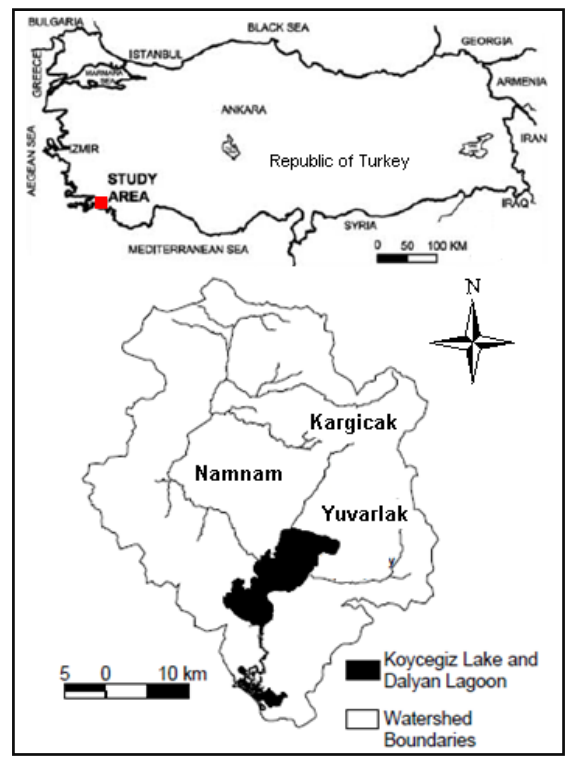

Figure 1: The geographical location of the study area.

\section{Data analysis}

Meteorological time series of precipitation, evaporation, average humidity, wind speed, wind direction and temperature were purchased from the Turkish State Meteorological Works (SMW) for the five stations within and surrounding the watershed. Meteorological data analysis was conducted by Yuceil et al. [21], and Koycegiz Station was selected as the most representative meteorological station for the watershed. Solar radiation and potential evapotranspiration were computed using the functions within the WDMUtil component of BASINS. The maximum and minimum temperature were estimated from 8 hourly measurements using a correlation between the maximum temperature and minimum temperature and the 8 hourly temperature measurements for the year 1998 for which measured maximum, minimum and mean air temperatures were available. Dew point temperature was estimated using Magnus-Tetens formula from the humidity measurements [22]. Solar radiation was computed using the monthly average values of cloud cover for the watershed in the WDMUtil computation tool. Evaporation data was available for the months of April to December. The missing data sets were estimated using Penman pan evaporation computation feature within WDMUtil. Flow rate datasets for the Namnam stream were retrieved from the State Hydraulic Works (SHW). These datasets comprised measurements from a single monitoring station on Namnam stream from 1980 to 1986 , and from 1990 to 1999. 


\section{Methods}

\subsection{Watershed delineation and characterization}

The Namnam sub-basin was divided into 4 sub-watersheds and four reaches as shown in Figure 2. The total area of the sub-watershed is approximately 487 square kilometers. Land use categories were condensed into 5 main categories to simplify the modeling process. The major land use/cover in the watershed is forest, with pasture and shrub land as the next most abundant type. Section PWATER, IWATER and HYDR were activated in the UCI file for the simulation of basic hydrology and flow routing in PERLND, IMPLND and RCHRES modules of the model. The model network was defined such that an outlet for reach 3 is located at the Namnam gauge station. Therefore, flow from reach 3 will be used for calibration and validation of the hydrologic model.

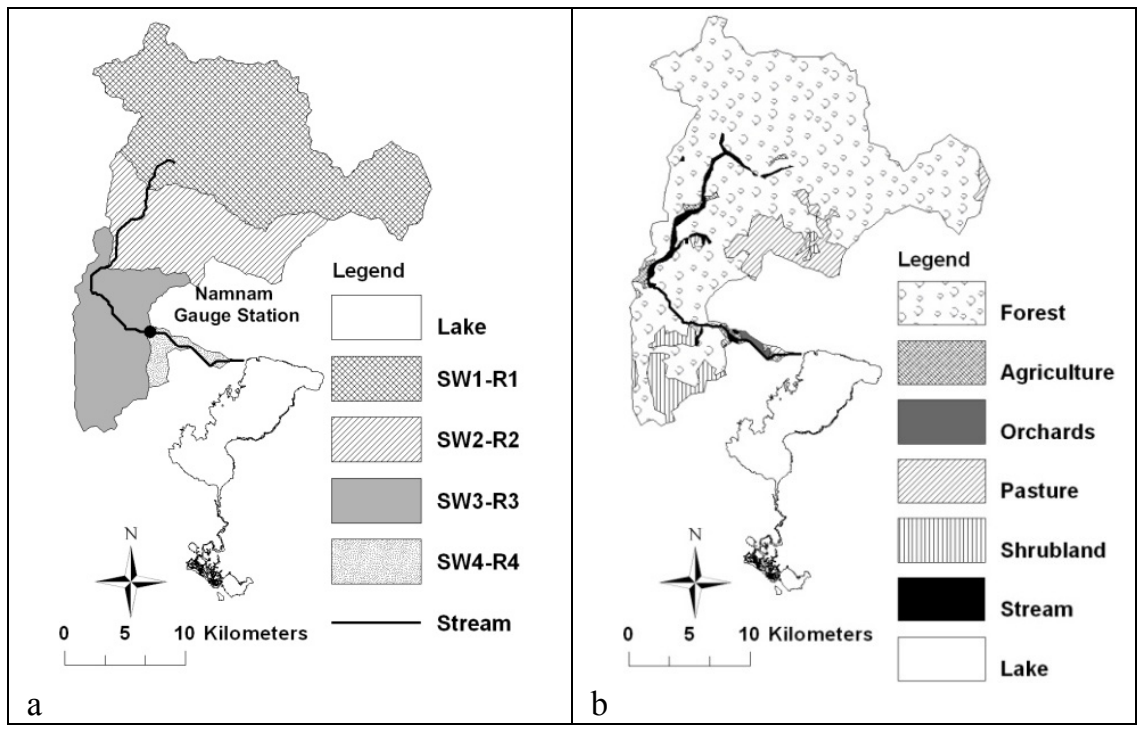

Figure 2: $\quad$ Delineated watershed a) Model setup and b) Land cover.

\subsection{Calibration strategy for Namnam hydrological model}

Calibration of HSPF is a systematic analysis of errors or differences between model simulated predictions and field observations which requires considerable effort and an expert understanding of the model processes and watershed characteristics. The Expert System for Calibration of HSPF (HSPEXP) developed by Lumb et al. [10] was used for the determination of a single set of parameters capable of representing the entire range of flow data at Namnam gauge station. HSPEXP uses 35 rules involving over 80 conditions to recommend parameter adjustments. The rules are divided into 4 hierarchy-based ordered phases of annual volumes, low flows, storm flows, and seasonal flows. 
The rules in individual phases are tested and, once satisfied, the system moves to the next phase. Numerous iterative simulations, comparison, and parameter modification steps were carried out based on specific hydrologic components of calibration effort. The length of surface runoff (LSUR), the slope of surface runoff (SLSUR), and Manning's roughness for the surface runoff (NSUR) were determined based on the physical characteristics in the watershed and the guidelines provided in the BASINS technical note number 6 [23].

\subsection{Modelling sediment and NPS pollutant loads}

The HSPF user control input file for the calibrated and validated hydrological model was modified for the inclusion of SEDMNT and PQUAL modules that simulate sediment and water quality constituents within WinHSPF. Sediment, nitrate-N, orthophosphate-P, and BOD were included in the UCI file to determine their loadings from each individual land use. Due to lack of calibration data parameter values, the parameterization of the SEDMNT and PQUAL was carried out based on BASINS Technical Note 8 [24] and literature values respectively.

\section{Results and discussion}

\subsection{Hydrologic calibration}

Considering the availability of observed flow data, a calibration period of $1^{\text {st }}$ October 1995 to $30^{\text {th }}$ September 1999 was selected for simulation of watershed hydrology. The hydrologic model was validated using flow data for the period $1^{\text {st }}$ October 1990 to $30^{\text {th }}$ September 1995. The graphical comparisons and statistical tests recommended by Donigian [25] were used for the verification of the hydrologic model. The performance of the model calibration based on HSPEXP criteria is presented in Table 1.

Table 1: $\quad$ Model calibration performance based on HSPEXP criteria.

\begin{tabular}{|c|c|c|c|c|c|}
\hline Flow Component (units) & Simulated & Observed & $\%$ Error & Criteria & Status \\
\hline Total Runoff (in) & 118.90 & 122.692 & -3.1 & $10 \%$ & Very Good \\
\hline $\begin{array}{l}\text { Total of Highest } 10 \% \text { Flows } \\
\text { (in) }\end{array}$ & 54.29 & 56.667 & -4.2 & $15 \%$ & Very Good \\
\hline $\begin{array}{l}\text { Total of Lowest } 50 \% \text { flows } \\
\text { (in) }\end{array}$ & 6.080 & 9.448 & -35.6 & $10 \%$ & Poor \\
\hline Evapotranspiration, (in) & 11.020 & 11.130 & 1.0 & $10 \%$ & Very Good \\
\hline Total storm volume (in) & 27.120 & 33.260 & -18.46 & $10 \%$ & Fair \\
\hline Average of storm peaks ( $\mathrm{cfs}$ ) & 1967.731 & 2420.667 & -18.7 & $15 \%$ & Fair \\
\hline Summer Flow Volume (in) & 1.750 & 5.940 & -70.53 & $10 \%$ & Poor \\
\hline Winter Flow Volume (in) & 72.640 & 67.727 & 7.25 & $10 \%$ & Good \\
\hline Summer Storm Volume(in) & 0.00 & 0.00 & 0.00 & $15 \%$ & -- \\
\hline $\begin{array}{l}\text { Base Flow Recession rate } \\
\text { (ratio) }\end{array}$ & 0.930 & 0.920 & 0.01 & 0.01 & Good \\
\hline Total Interflow(in) & 19.290 & --- & -- & --- & --- \\
\hline Total Surface Runoff (in) & 4.260 & --- & --- & --- & --- \\
\hline
\end{tabular}


A comparison of calibrated parameter values with values from literature are presented in Table 2 and Table 3 presents the Linear Correlation Coefficient (R) values. The plots of daily mean flows for observed and simulated flows (Figure 3 for calibration and Figure 4 for validation) show considerable consistency in identifying storm events; however, the simulated results lack consistency in showing low flow conditions.

Table 2: $\quad$ Calibrated parameters comparison with other studies.

\begin{tabular}{|c|c|c|c|c|c|c|}
\hline Parameter & Units & $\begin{array}{l}\text { This } \\
\text { Study }\end{array}$ & $\begin{array}{l}\text { Im et al } \\
{[26]}\end{array}$ & $\begin{array}{l}\text { Albek et al } \\
{[19]}\end{array}$ & $\begin{array}{l}\text { Saleh \& Du } \\
{[27]}\end{array}$ & $\begin{array}{l}\text { Choi \& Deal } \\
{[4]}\end{array}$ \\
\hline LZSN & $\mathrm{mm}$ & $\begin{array}{c}53.34- \\
112 \\
\end{array}$ & $\begin{array}{l}109.22- \\
147.32 \\
\end{array}$ & 80.0 & 152.4 & 203.2 \\
\hline INFILT & $\mathrm{mm} / \mathrm{hr}$ & 20.32 & $\begin{array}{l}1.1938- \\
1.905\end{array}$ & 20.0 & 4.064 & 2.79 \\
\hline AGWRC & None & $\begin{array}{c}0.85- \\
0.91 \\
\end{array}$ & $\begin{array}{l}0.88- \\
0.91 \\
\end{array}$ & 0.99 & 0.98 & 0.975 \\
\hline UZSN & $\mathrm{mm}$ & $\begin{array}{l}30.48- \\
35.56\end{array}$ & $\begin{array}{l}8.89- \\
25.4\end{array}$ & 15.0 & 28.6512 & 20.3 \\
\hline DEEPFR & None & $\begin{array}{l}0.2- \\
0.5\end{array}$ & $\begin{array}{l}0.05- \\
0.45\end{array}$ & 0.35 & 0.8 & 0.15 \\
\hline LZETP & None & $\begin{array}{l}0.1- \\
0.7 \\
\end{array}$ & $\begin{array}{l}0.2- \\
0.7 \\
\end{array}$ & 0.1 & 0.6 & 0.2 \\
\hline INTFW & None & $\begin{array}{l}1.0- \\
8.0\end{array}$ & $\begin{array}{l}1.0- \\
1.7\end{array}$ & 2.0 & 2.5 & 1.7 \\
\hline IRC & None & $\begin{array}{c}0.2- \\
0.4 \\
\end{array}$ & $\begin{array}{l}0.3- \\
0.5 \\
\end{array}$ & 0.65 & 0.5 & 0.7 \\
\hline
\end{tabular}

Table 3: $\quad$ Model calibration performance results after Donigian [25].

\begin{tabular}{|lllllll|}
\hline \multicolumn{2}{c}{ Calibration Period } & \multicolumn{2}{c|}{ Validation Period } & \multicolumn{2}{l|}{ Entire Period } \\
1995-1999 & & $\mathbf{1 9 9 0 - 1 9 9 9 4}$ & \multicolumn{2}{l|}{ Oct. 1990- Sep. 1999 } \\
& Mean & Mean & Mean & Mean & Mean & Mean \\
\multirow{2}{*}{ Result } & Daily & Monthly & Daily & Monthly & Daily & Monthly \\
Status & 0.634 & 0.847 & 0.761 & 0.843 & 0.638 & 0.838 \\
& Poor & Fair & Fair & Fair & Poor & Fair \\
\hline
\end{tabular}

Figure 5 shows the comparison of the FDCs for the observed and simulated flows. The FDCs have been divided into five zones. The shape of the simulated FDC for the first three zones of high flows, moist conditions, and mid range flows follow an approximately similar shape and slope to that of the observed FDC, thereby representing the hydrologic regime in the watershed for approximately $60 \%$ of the flows. However, as seen from the calibration and validation results, the FDC for simulated flows in the dry conditions and low flow zones do not exhibit similar properties to that of the observed FDC. Steeper slope for the simulated flows in dry conditions represent a highly variable system with stream flow largely driven by direct runoff with limited ground water storage capacity. Considering typical Mediterranean climatic conditions and lack of data for exact representation of soil infiltration characteristics and groundwater interactions in the watershed, this anomaly in simulated flows may 
be credited to high evaporation and infiltration rates during the summer months, which is also evident from the lack of sustained base flow shown in the observed flow's FDC.

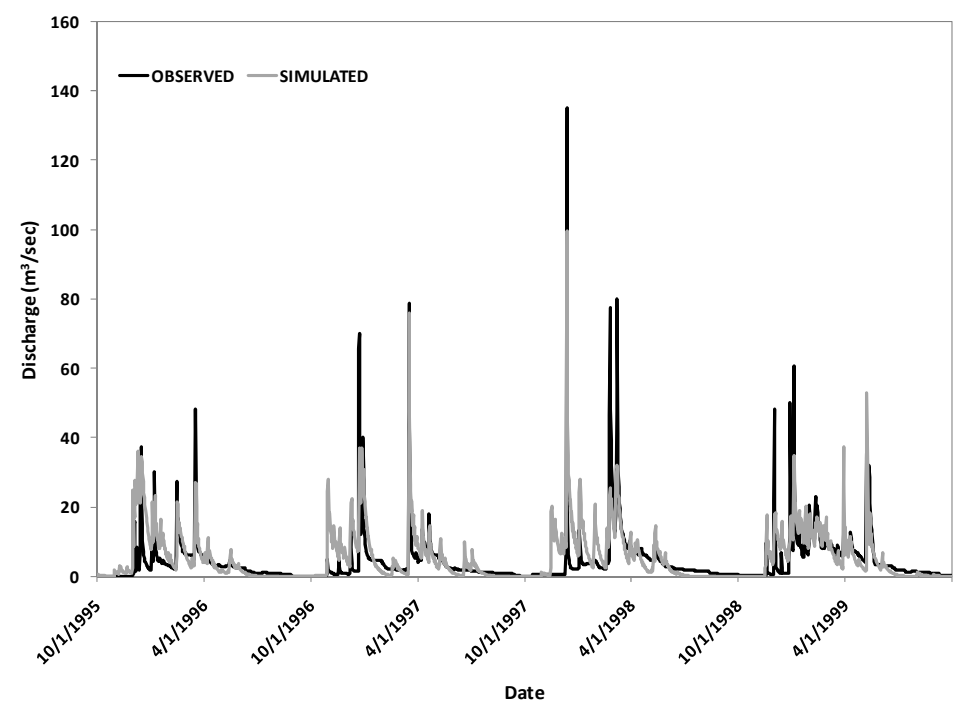

Figure 3: Calibration-standard plots for observed and simulated daily flows at Namnam (1995-1999).

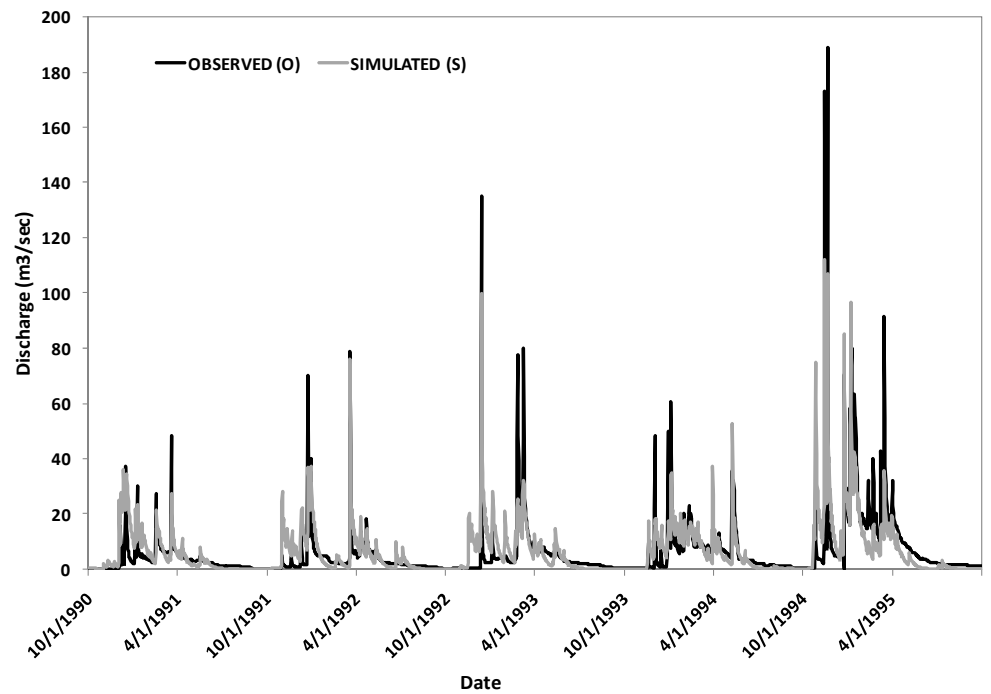

Figure 4: Validation-standard plots for observed and simulated daily flows at Namnam (1990-1994). 
Furthermore, considering the objectives of the study and the pollution sources within the watershed, the representation of low flows may not be an important factor in simulated flows. Nonpoint sources are typically associated with runoff events in the midrange, moist and high flow conditions, whereas dry conditions may be critical for point source's discharges into the stream. Due to the lack of point sources in the watershed, the incongruity of low flows in the model results does not pose any serious issues for study objectives.

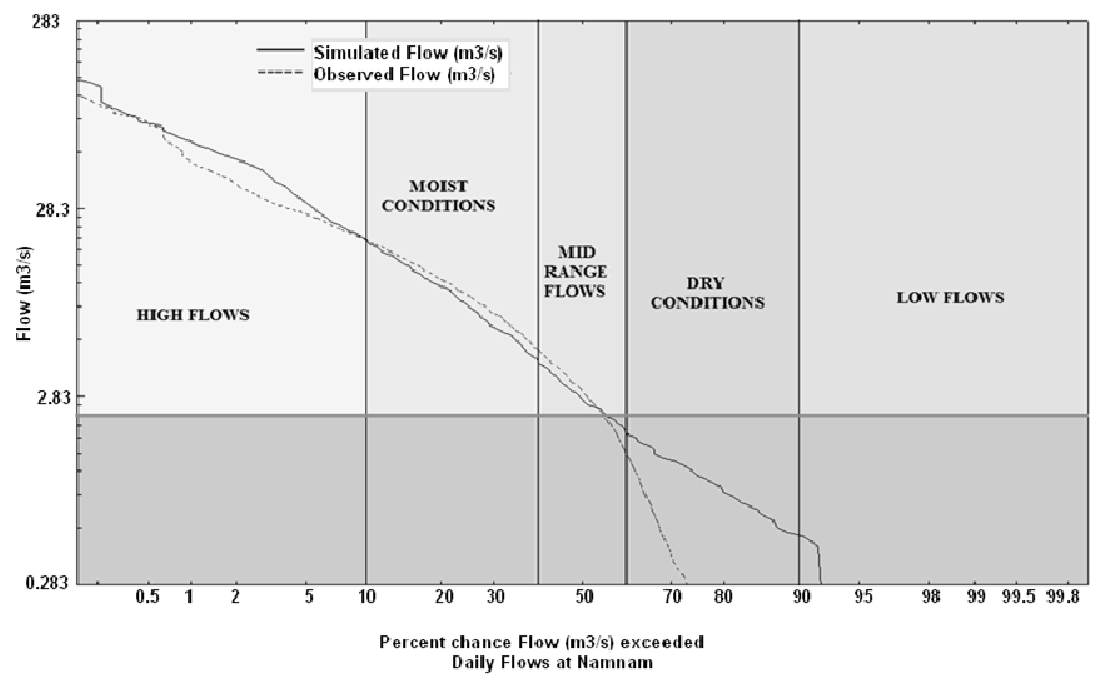

Figure 5: $\quad$ Flow duration curves for observed and simulated flows.

\subsection{NPS pollutant loads}

The distribution of mean annual fluxes is shown in Figure 6. Due to unavailability of measured water quality data, the results for the NPS pollutant loads could not be calibrated. The HSPF parameter database tool HSPFParm was used to estimate the parameters for the simulation of NPS pollutant loads in the watershed [11]. Furthermore, the annual fluxes were determined for the simulated NPS pollutants considering that uncertainty of the estimates of pollutant yield decreases with increasing average time, e.g. a predicted annual flux is more precise than an instantaneous or daily flux [28]. The model calculated fluxes for Nitrate-N and Ortho-Phosphates were compared with land use type export coefficients from the literature [29] for Total Nitrogen (TN) and Total Phosphorus (TP). This provided some degree of assessment of the model generated results. The model calculated values were comparable with range values from literature considering the model calculated constituents accounted for specific forms of Nitrogen and Phosphorus compared to values of TN and TP from the literature as shown in Table 4. The sediment flux from the watershed has an approximately even distribution from agriculture, pasture and shrubland; 
however, it was highest from the orchards with forested land generating the lowest percent of mean annual flux. Orchards represent $1 \%$ of the total area, but contribute $32 \%$ of annual sediment flux. Forests cover $81 \%$ of the total land area, but contribute $8 \%$ of total sediment load flux. The total mean annual sediment flux was highest in the year 1998 and the least in 1993 within the simulated period of 1991-1998. The pollutants' flux from the pasture land use type was 63, 72 and $68 \%$ for Nitrates-N, Orthophosphates-P, and BOD, respectively, whereas it was approximately evenly distributed from the rest of the land uses in the watershed. The higher pollutant loads from the pasture land use type can be attributed to cattle grazing activities.

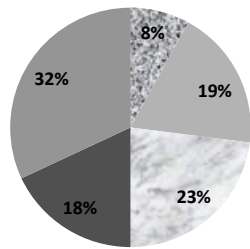

a

A FOREST

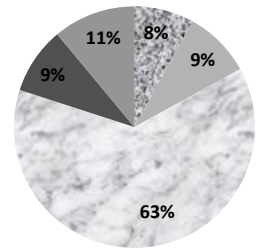

b

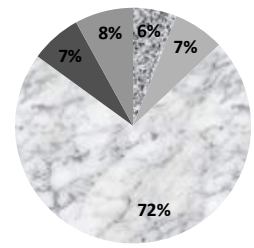

c

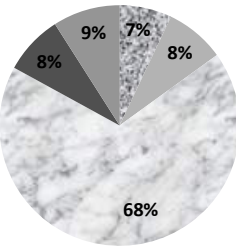

d

PASTURE

SHRUBLAND

ORCHARDS

Figure 6: Annual NPS pollutant flux distribution among different land uses a) sediment, b) nitrate-N, c) orthophosphate-P and d) BOD.

Table 4: Comparison of model generated results with export coefficients [29].

\begin{tabular}{|c|c|c|c|c|c|c|}
\hline $\begin{array}{l}\text { LAND } \\
\text { USE }\end{array}$ & $\begin{array}{c}\text { NITRATE } \\
-\mathrm{N} \\
(\mathrm{kg} / \\
\left.\mathrm{km}^{2} / \mathbf{y r}\right)\end{array}$ & $\begin{array}{c}\text { TN } \\
(\mathrm{kg} / \\
\left.\mathrm{km}^{2} / \mathrm{yr}\right)\end{array}$ & $\begin{array}{c}\text { TN Range } \\
(\mathbf{k g} / \\
\left.\mathrm{km}^{2} / \mathbf{y r}\right)\end{array}$ & $\begin{array}{c}\text { ORTHO- } \\
\text { P } \\
(\mathbf{k g} / \\
\left.\mathbf{k m}^{2} / \mathbf{y r}\right)\end{array}$ & $\begin{array}{c}\text { TP } \\
(\mathrm{kg} / \\
\left.\mathrm{km}^{2} / \mathrm{yr}\right)\end{array}$ & $\begin{array}{c}\text { TP Range } \\
(\mathrm{kg} / \\
\left.\mathrm{km}^{2} / \mathbf{y r}\right)\end{array}$ \\
\hline Forest & 316 & 286 & $138-626$ & 4 & 24 & $19-83$ \\
\hline $\begin{array}{l}\text { Agricultur } \\
\mathrm{e}\end{array}$ & 368 & 1653 & $282-4150$ & 4 & 113 & $8-325$ \\
\hline Pasture & 2490 & 865 & $148-3085$ & 41 & 150 & $14-490$ \\
\hline Shrubland & 349 & NA & NA & 4 & NA & NA \\
\hline Orchards & 424 & 519 & $97-782$ & 5 & 108 & $10-290$ \\
\hline
\end{tabular}

\section{Conclusions}

This study and its results demonstrate that a complex, highly parameterized dynamic simulation model (in this case HSPF) can, in fact, be used to perform watershed management centric modeling and analysis tasks under relatively data-poor conditions. Indeed the availability of free and well documented software models and data preparation tools as used here can be a boon to researchers and environmental resource managers working in developing 
countries if proper consideration is given to understanding their inherent limitations and specific compounding factors related to data availability. The current work should serve as an example approach that can be taken by others working to better understand and manage similarly important environmental resources with challenging data constraints.

\section{References}

[1] Reimold, R. J., 1998. Watershed Management Practice, Policies, and Coordination, McGraw-Hill, New York.

[2] Baloch, M. A., \& Tanik, A., 2008. Development of an Integrated Watershed Management strategy for Resource Conservation in Balochistan Province of Pakistan. Desalination 226, 38-46.

[3] Ames, D. P., Neilson, B. T., Stevens, D. K., and Lall, U., 2005. "Using Bayesian networks to model watershed management decisions: an East Canyon Creek case study." J. Hydroinformatics, 7(4), 267-282.

[4] Choi, W \& Deal, B.M., 2008. Assessing hydrological impact of potential land use change through hydrological and land use change modeling for the Kishwaukee River basin (USA). J. of Environ. Management 88, 1119 1130.

[5] Singh, J., Vernon Knapp, H., Arnold, J. G. \& Demissie, M., 2005. Hydrological modeling of the Iroquois river watershed using HSPF and SWAT. Journal of the American Water Resources Association 41, (2), 343360 .

[6] Mishra, S. K. \& Singh, V.P., 2004. Long-term hydrological simulation based on the Soil Conservation Service curve number. Hydrol. Process. 18, 1291-1313.

[7] Luo, B., Li, J.B., Huang, G.H. \& Li, H.L., 2006. A simulation-based interval two-stage stochastic model for agricultural nonpoint source pollution control through land retirement. Science of the Total Environment 361, 38- 56 .

[8] US EPA, Office of Water, 2007. Better assessment Science Integrating point and Nonpoint Sources BASINS 4.0, User's Manual. EPA-823-C-07001 .

[9] Ames, D. P., Michaelis, C., Anselmo, A., Chen, L., and Dunsford, H., 2008. MapWindow GIS. Encyclopedia of GIS. Sashi Shekhar and Hui Xiong (Editors). Springer, New York, pp. 633-634.

[10] Lumb, A.M., McCammon, R.B., \& Kittle, J.L., Jr., 1994. Users' manual for an expert system (HSPEXP) for calibration of the Hydrologic Simulation Program--Fortran: USGS Water-Resources Investigations Report 94-4168.

[11] Donigian, A. S. Jr., Imhoff, J. C. \& Kittle, J. L. Jr., 1999. HSPFParm: An Interactive Database of HSPF Model Parameters. EPA-823-R-99-004. U.S. EPA Office of water, Washington DC, USA.

[12] Baloch, M. A., Tanik, A., 2009. Watershed modeling: Application of BASINS for the delineation and characterization of Namnam watershed. itüdergisi/e su kirlenmesi kontrolü (Journal of Istanbul Technical 
University/E - Water Pollution Control), Vol:19, Issue:1-2, 85-97 (In Turkish).

[13] Hayashi, S., Murakami, S., Watanabe, M., Bao-Hua, X., 2004. HSPF Simulation of Runoff and Sediment Loads in the Upper Changjiang River Basin, China. Journal of Environ. Engineering 130 (7), 801- 815.

[14] Chung, E.-S. and K. S. Lee (2009). "Prioritization of water management for sustainability using hydrologic simulation model and multicriteria decision making techniques." J. of Environ. Management 90(3): 1502-1511.

[15] Bicknell, B.R., Imhoff, J., Kittle, J. and Donigian A., 2001. Hydrological Simulation Program-Fortran (HSPF). User's Manual for Release 12. U.S. EPA National Exposure Research Laboratory, Athens, GA.

[16] Rahman, M. \& Salbe, I., 1995. Modeling Impacts of Diffuse and PointSource Nutrients on the Water-Quality of South-Creek Catchment. Environment International 21 (5), 597-603.

[17] Laroche, A.M., Gallichand, J., Lagace, R., \& Pesant, A. (1996) Simulating atrazine transport with HSPF in an agricultural watershed. Journal of Environmental Engineering-ASCE 122, 622-630.

[18] Al-Abed, N. A. \& Whiteley, H. R., 2002. Calibration of the Hydrological Simulation Program Fortran (HSPF) model using automatic calibration and geographical information systems. Hydrol. Process. 16, 3169-3188.

[19] Albek, M., Öğütveren, Ü. B. \& Albek, E., 2004. Hydrological modeling of Seydi Suyu watershed (Turkey) with HSPF, J. Hydrol. 285, 260-271.

[20] Goncu, S., \& Albek, E., 2007. Modeling the Effects of Climate Change on Different Land Uses. Water Science and Technology 56:1, 131-138.

[21] Yuceil, K., Baloch, M. A., Gonenc, E. \& Tanik, A., 2007. Development of a Model Support System for Watershed Modeling: A Case Study from Turkey. CLEAN - Soil, Air, Water 35(6), 638 - 644.

[22] Lawrence, M. G., 2005. The relationship between relative humidity and the dew point temperature in moist air: A simple conversion and applications. Bull. Am. Meteorol. Soc. 86, 22.

[23] US EPA, 2000. BASINS Technical Note 6: Estimating Hydrology and Hydraulic Parameters for HSPF. US EPA-823-R00-012.

[24] US EPA, 2006. BASINS Technical Note 8: Sediment Parameter and Calibration Guide for HSPF. US EPA, Office of Water 4305.

[25] Donigian, Jr., A.S.J., 2002. Watershed Model Calibration and Validation: The HSPF Experience. National TMDL Science and Policy 2002 Specialty Conference, 30:1, Water Environment Federation, Alexandria, Virginia, USA.

[26] Im, S.J., Brannan, K.M. \& Mostaghimi, S. (2003) Simulating hydrologic and water quality impacts in an urbanizing watershed. Journal of the American Water Resources Association 39:1465-1479.

[27] Saleh, A., and B. Du. 2004. Evaluation of SWAT and HSPF within BASINS program for the upper North Bosque River watershed in central Texas. Trans. ASAE 47(4): 1039-1049.

[28] Peters, N.E., Reynolds, B., and Johnes, P.J., 2007.Uncertainty of waterquality predictions in ungauged basins (PUBs). Predictions in Ungauged 
Basins: PUB Kick-off (Proceedings of the PUB Kick-off meeting held in Brasilia, 20-22 November 2002). IAHS Publ. 309

[29] Lin, J.P., 2004. Review of Published Export Coefficient and Event Mean Concentration (EMC) Data. ERDC TN WRAP 04 03. U.S. Army Corps of Engineers, Engineer Research and Development Center, Vicksburg, MS. 